\title{
HABITAT AND RANGE EXTENSION OF COBAEA LUTEA (POLEMONIACEAE) IN WESTERN MEXICO
}

\author{
Eduardo SaHagún-Godínez \\ José Aquileo Lomelí-Sención \\ Jardín Botánico y Herbario \\ Universidad Autónoma de Guadalajara \\ Apartado postal 1-440 \\ 44100 Guadalajara, Jalisco, México \\ esahagun@uagunix.gdl.uag.mx jalomeli@icb.gdl.uag.mx \\ AND \\ L. Alan Prather \\ Department of Botany and Plant Pathology \\ Michigan State University \\ East Lansing, MI 48824-1312, USA \\ alan@msu.edu
}

\begin{abstract}
For the first time we present evidence of the presence of Cobaea lutea D. Don in tropical deciduous forest; we propose an hypothesis to explain this event and discuss the variety of habitats occupied by this and other members of the Polemoniaceae. We analyze the extension of the geographic limits of C. lutea ca. $350 \mathrm{~km}$ northwestwards from the "Sierra Madre del Sur" in Guerrero to the "Eje Neovolcánico" in Jalisco. We also document the presence of densely long-villous pedicels as a morphological variant of $C$. lutea, and present a description and an illustration.
\end{abstract} Mexico.

Key words: Cobaea, Polemoniaceae, tropical deciduous forest, phenotypic plasticity, western

\section{RESUMEN}

Por primera vez se registra la presencia de Cobaea lutea D. Don en bosque tropical caducifolio; se propone una hipótesis para explicar este evento y se discute la diversidad de hábitats ocupados por éste y otros miembros de las Polemoniaceae. Se analiza la extensión de los límites geográficos de C. lutea ca. $350 \mathrm{~km}$ hacia el noroeste, desde la Sierra Madre del Sur en Guerrero hasta el Eje Neovolcánico en Jalisco. Se documenta la presencia de pedicelos densamente vilosos como una variante morfológica de $C$. lutea y se describe e ilustra este taxon.

Palabras clave: Cobaea, Polemoniaceae, bosque tropical caducifolio, plasticidad fenotípica, occidente de México. 


\section{INTRODUCTION}

There are 18 known species in the genus Cobaea Cav. Of these, 10 occur in Mexico and four, all in section Cobaea, are endemic to this country (Prather, 1999). The genus is characterized by its scandent habit and pinnately compound leaves with the terminal leaflets modified into tendrils. The flowers are large and campanulate, the pollen grains are reticulate, and the fruits are septicidal (Prather, 1996).

The species of Cobaea are known to occur in humid montane forests of tropical America (Standley, 1914; Gibson, 1970; Ippolito \& Suárez, 1998). The habitat extension of C. lutea D. Don presented here is significant because it could indicate that the lack of specimens in herbaria of this and perhaps other species of Cobaea from low elevation tropical regions may be due in part to the oversight of collectors of these green-flowered plants in the vine-entangled vegetation of tropical deciduous forests.

For many years Cobaea lutea was regarded as a species of South and Central America, with its northernmost known record in Guerrero. Only recently have new populations been found as far north as Zacoalco in Jalisco, ca. $350 \mathrm{~km}$ northwest of the Guerrero populations. This distance is more significant than it would seem at first glance due to the ruggedness of the terrain.

The objectives of this article are to 1) document the presence of Cobaea lutea in tropical deciduous forest, 2) compare this to the habitats occupied by other polemoniaceous genera, 3) propose an hypothesis to account for the habitat expansion, and 4) report a significant extension in the geographic range to the northwest.

\section{METHODS}

In March 1997 fruits from a population of Cobaea located at Las Moras in the municipio of Zacoalco, Jalisco were collected. Seeds were sown at Jorge Victor Eller Botanical Garden that summer. Herbarium specimens were prepared when the plants flowered in October. The following year, additional seeds from the initial collection were again sown. Photographs and a line drawing were prepared from these cultivated plants. Additional herbarium material was prepared from plants growing in the wild at Las Moras during a collection trip in October 1998. This material was used to adapt the description of C. lutea given in Prather (1999).

All herbarium specimens were deposited at Carlos Luis Díaz Luna Herbarium of Universidad Autónoma de Guadalajara (GUADA). Additional specimens of $C$. lutea housed in other herbaria (CAS, F, GH, IBUG, K, MEXU, MO, MSC, NY, RSA, TEX, UC, US, WIS) were also examined. Other herbaria were consulted but they had no specimens of $C$. lutea for locations north of Guerrero (CHAPA, ENCB, UAMIZ and XAL).

\section{RESULTS}

A population of $C$. lutea at Las Moras was found mixed with other vines (Cucurbita sp., Sechiopsis triquetra and Quamoclit sp.) in one of the main ravines stemming down from 
the oak and pine forest areas located higher in the Sierra de Tapalpa. The plants were abundant, although localized, in tropical deciduous forest with Lysiloma acapulcense, Montanoa sp., Bursera spp., Ipomoea murucoides, Euphorbia cotinifolia, Ptelea trifoliata, Viguiera quinqueradiata, Tillandsia dasyliriifolia and Tillandsia spp.

In an effort to explain the presence of Cobaea lutea in the drier habitats of western Mexico, we propose the following hypothesis. Cobaea lutea in this region is likely a relict from widespread ancestral populations that lived in a more humid climate and now is found only in favored sites in ravines. We also believe that a combination of adaptations such as an annual habit and a vigorous scandent form have allowed $C$. lutea to survive in a seasonally drier environment. We present support for this hypothesis in the discussion.

The population located at Las Moras is currently the northernmost known. A description of Cobaea lutea follows to aid in its identification. Range values in brackets were measured from the specimens collected at Las Moras.

Cobaea lutea D. Don, Edinburg Phil. J. 10: 112. 1824. Fig. 1.

Annual vine, 5-8 m long. Stems usually slender, sometimes puberulent at the nodes. Leaves alternate, pinnately compound, with 6 opposite or subopposite leaflets, the terminal leaflet modified into a branched tendril, each branch terminated with two claws; rachis 23$70 \mathrm{~mm}$ long; petiolules [2] 3-7 mm long; leaflets 24-110 [130] mm long, 11-60 mm wide, elliptic to elliptic-oblanceolate, rarely obovate, glabrous or puberulent along the veins, margins minutely ciliate and sometimes long-ciliate at the base, base acute to truncate to cordate, apex acute to acuminate. Inflorescence a dichasial cyme of 1-5 flowers, subtended by foliaceous bracts. Peduncles (2.3) 6.3-10.0 (15.0) cm long, glabrous or puberulent at the base and apex. Pedicels (8.2) $14.3-25.0 \mathrm{~cm}$ long, glabrous or puberulent at the base and apex, sometimes long-villous, coiled in fruit. Calyx segments 5, 19-28 mm long, 3.5-8.0 mm wide, essentially distinct, green, rarely suffused with red or purple, lanceolate to lanceolateovate, apex acute to acuminate, minutely ciliate and sometimes also long-ciliate. Corollas green, rarely greenish-yellow or suffused with purple or red, puberulent or sometimes villous externally on the upper tube and the base of the lobes, glabrous internally except for the long-villous annulus; tube 17-37 mm long, 19-35 mm wide, campanulate; lobes 5, 13-30 mm long, $10-18 \mathrm{~mm}$ wide, broadly ovate, narrowing to an acuminate to long-acuminate apex, slightly imbricate. Stamens 5; filaments $34-80 \mathrm{~mm}$ long, adnate basally to the corolla tube for 4-9 mm, emergent or slightly reflexed; anthers [6] 7-14 mm long, [1] 1.5-2.5 mm wide, yellow, linear to lanceolate, versatile. Ovary superior, inserted on a large five-lobed nectary disk, tricarpellate, trilocular, ovate, glabrous, septa thickened and fused into a central column which is triangular in cross section; styles 65-78 (90) mm long; style branches 3, 8-13.5 mm long, terete, papillae short, covering nearly the entire surface. Fruit a capsule, exceeding the calyx, 20-58 mm long, septicidal, elliptic to narrowly elliptic. Seeds 6-21 per fruit, flat, ovate to broadly ovate, 16-21 [24] mm long including the wing, [10] 11-12 [13] mm wide including the wing; wings $2-4 \mathrm{~mm}$ wide.

Phenology. Flowering in September-December. Fruiting in October-March.

Distribution. Peru, El Salvador, Honduras, Guatemala and Mexico (Chiapas, Guerrero, Colima, and Jalisco). This species occurs in cloud forests, semi-deciduous forests, 

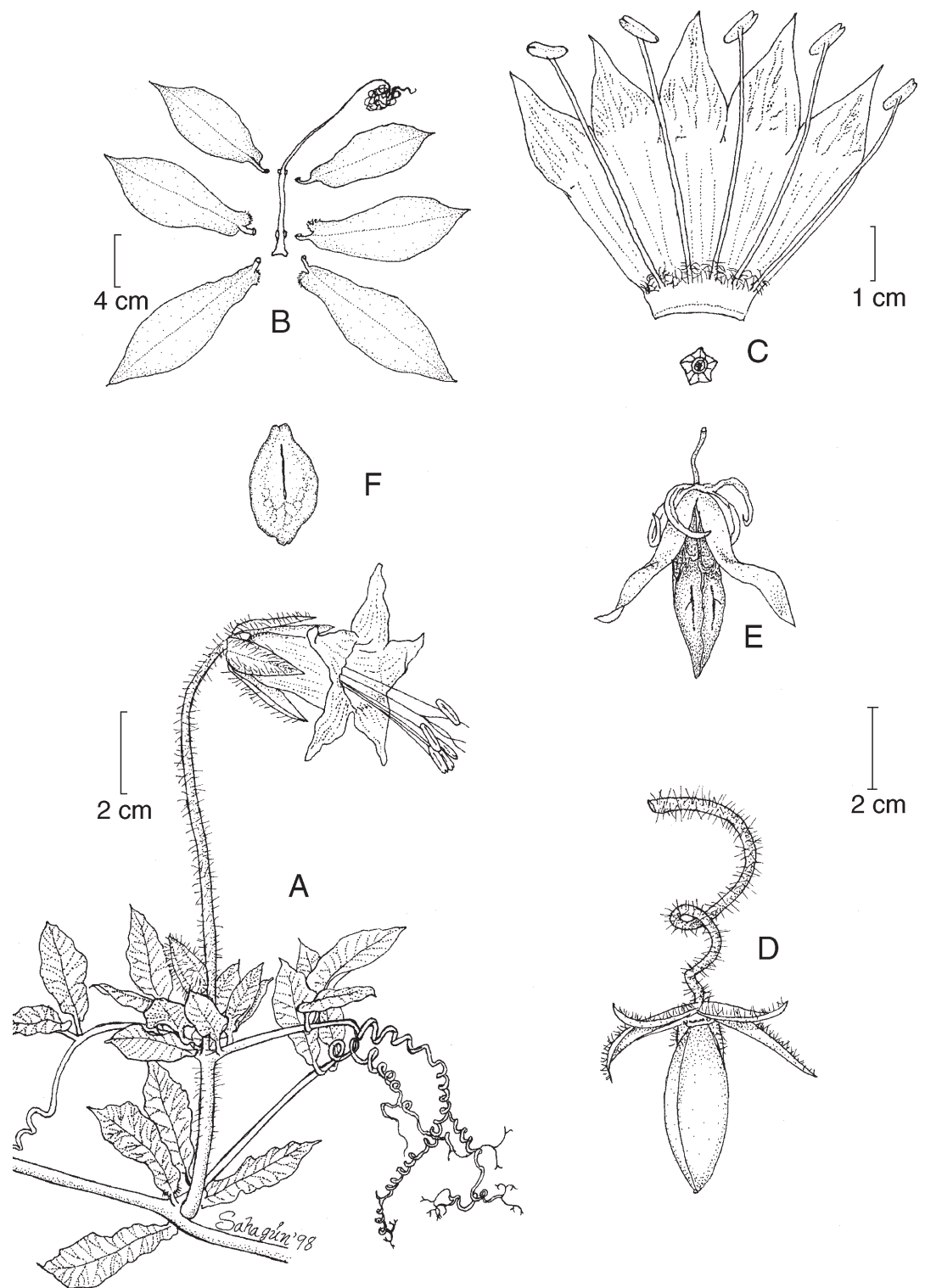

Fig. 1. Cobaea lutea. A. Portion of plant with inflorescence. B. Leaf with detached leaflets. C. Dissected corolla showing insertion of stamens, long-villous annulus and nectary disk. D. Immature fruit with coiled pedicel showing densely long-villous pubescence. E. Dehisced fruit showing persistent calyx, septal column and filamentous placentae. F. Winged seed. All drawings from a plant cultivated at Jorge Victor Eller Botanic Garden, except for B, from J. A. Lomelí 2928. 
tropical deciduous forest and forested foothills of the Pacific coastal regions of North and South America; 300-2200 m above sea level.

Specimens seen: COLIMA: Rancho "El Jabalí" 20 km (airline distance) N of Colima in the SW foothills of the Volcán de Colima. From the Jabalí main gate to Hacienda San Antonio along the road to Comala. Near 19026.09'N 103²4'W, A. C. Sanders 11946 w/L. Vázquez V. (CAS, MEXU). JALISCO: Sierra de Manantlán Biosphere Reserve, near Colima boundary, zone of permanently cultivated areas intercalated with extensive chaparral, right below SE edge of Cerro Toxín in bottom of arroyo Pitahayas, $1 \mathrm{~km} \mathrm{NE}$ of Toxín, barely $\mathrm{N}$ of Puerto de Toxín-La Loma crossroads, along El Sauz-San Pedro Toxín Rd. 13 km (airline distance) NNE of Minatitlán, $39 \mathrm{~km}$ due NW of Colima, T. Cochrane et al. 12268 (MSC, WIS-2); Mpio. Zapotitlán, rancho El Jabalí, $22 \mathrm{~km}$ (airline) $\mathrm{N}$ of Colima in the SW foothills of the Volcán de Colima, La Joya area, $\mathrm{N}$ of the airstrip and S of Arroyo Santa Cruz, E of Cerro El Campanario, A. C. Sanders 11666 (CAS); Mpio. de Zacoalco, cañada en ladera al NW de Las Moras, bosque tropical caducifolio, J. A. Lomelí-Sención s. n. Octubre 1997 (GUADA); Mpio. de Zacoalco, Las Moras, cañada ca. 200 m río arriba desde la Capilla de la ranchería $\left(20^{\circ} 09^{\prime} 30^{\prime \prime} \mathrm{N} 103^{\circ} 35^{\prime} 35^{\prime \prime W}\right)$, bosque tropical caducifolio, J. A. Lomelí-Sención 2928 (GUADA, IBUG, MEXU); ibid., J. A. Lomelí-Sención 3446 (GUADA). GUERRERO: District of Montes de Oca, San Antonio, G. B. Hinton 11671 (F, GH, K, MO, NY, RSA, UC, US); along Route 134 between Ciudad Altamirano and the intersection with Route 200, 19.2 km N of San Antonio, A. Prather 1220 with J. Soule (MEXU, TEX).

\section{DISCUSSION}

Most researchers agree that Cobaea is a genus of humid montane forests (Standley, 1914; Gibson, 1970; Ippolito \& Suárez, 1998), thus the new record from tropical deciduous forest is notable. Prather (1999) lists the habitat of most Cobaea species as mesic, tropical montane forests (often cloud forests), but notes that a few occur at lower altitudes. All Cobaea species were reported from mesic habitats, but Prather collected $C$. rotundiflora at one site in tropical deciduous forest in Guatemala at $975 \mathrm{~m}$ alt. (Prather 960, TEX). Cobaea rotundiflora is found more typically in mesic environments at higher elevations in Chiapas (Prather, 1999).

Likewise, $C$. lutea populations were known to occur only in more mesic habitats, from cloud forests to mesic forests of the foothills of the Pacific Coastal region in Guatemala and El Salvador. Thus, $C$. Iutea and $C$. rotundiflora share a similar breadth of habitat, have common centers of distribution (even though the extent of $C$. lutea distribution is much broader), are morphologically similar, and are closely related based on molecular data (Prather, 1999). Nonetheless, they are easily distinguished by calyx width, stamen length relative to corolla length, corolla shape, anther position and length of style branches (Prather, 1996).

It is possible that $C$. lutea may be widespread in tropical deciduous forests but it had not been collected due to the difficulty of locating the green-flowered plants in the dense vegetation. It is remarkable that, at Las Moras, it was difficult for us to find the flowers, even when we knew they were in front of us since we had located the population in flower when we were on our way down, on the other side of the creek. Cobaea lutea is much easier 
to detect when it is in fruit. The large capsules hanging from coiled pedicels evidence both location and identity.

The species of Cobaea are generally more mesic than most other species of the Polemoniaceae, including the other members of the subfamily Cobaeoideae. According to molecular data from the chloroplast genome, the genus Bonplandia is the sister group to the genus Cobaea (e.g. Johnson et al., 1996; Prather et al., 2000). Bonplandia is a monotypic genus that occurs mainly in tropical deciduous forests (Rzedowski \& Calderón de Rzedowski, 1995) from Tamaulipas and southern Sonora, south to Guatemala. The western South American genera Cantua and Huthia are also known to be related to Cobaea (Grant, 1998; Johnson et al., 1996; Prather et al., 2000) and occur mainly in dry shrublands and forests of the Andes (Weberbauer, 1945; Brako \& Zarucchi, 1993). Loeselia and Acanthogilia, are less closely related to Cobaea, but are distributed primarily (Loeselia) or exclusively (Acanthogilia) in Mexico. The species of Loeselia are found in a variety of habitats, from dry forests, to deciduous forests, and deserts (Rzedowski \& Calderón de Rzedowski, 1995) and Acanthogilia is found in deserts of the Baja Peninsula (Day \& Moran, 1986). The remainder of the species of the family occur in a variety of habitats, from deserts to vernal pools or stream banks, but the majority of species of the family are desert herbs of western North America (Grant, 1998).

In Mexico, Cobaea lutea is currently known to occur in Chiapas, Guerrero, Colima and Jalisco. It is expected in Oaxaca and Michoacán, which lie between known populations, but as far as we know, no specimens or published reports exist to confirm its presence there. Even where reported, $C$. lutea seems to be rare or at least little collected.

In Guerrero, the recently-compiled checklists that we reviewed do not include any species of Cobaea (Fonseca \& Lozada, 1993; Diego \& Lozada, 1994; Lozada, 1994; Gual, 1995; Peralta, 1995; Verduzco \& Rodríguez, 1995; Gallardo, 1996 and Vargas \& Pérez, 1996).

From the valley of Mexico, Calderón de Rzedowski (1985) had no record of the genus, but Argüelles et al. (1991) reported Cobaea scandens from nearby Querétaro. From the Bajío region, a thoroughly explored area which includes Guanajuato, Querétaro and portions of Michoacán, Rzedowski and Calderón de Rzedowski (1995) reported Cobaea scandens and C. stipularis only. Labat (1995) did not list any species of Cobaea in Michoacán, and neither did Barrios-Rodríguez and Medina-Cota (1996) from Sierra de Pachuca, in Hidalgo.

From Jalisco, no species of Cobaea were reported in the publications reviewed (Rzedowski \& McVaugh, 1966; Lott, 1985; Vázquez et al., 1995; Guerrero-Nuño \& LópezCoronado, 1997), except for Prather (1999).

As far as we know, the northernmost record of this species known in the literature is a specimen collected by Cochrane et al. (No. 12268) in the Manantlán Biosphere Reserve near the limits with the state of Colima, reported by Prather (1999). However, he did not discuss the significant range extension for this species, ca. $300 \mathrm{~km}$ northwest of the Guerrero populations (Fig. 2). The specimens collected by Lomelí (No. 2928, 3446) reported here further extend the range northwestward, ca. $350 \mathrm{~km}$ from the Guerrero collections. This population also occurs farther inland than other collections known from Mexico. The JaliscoColima specimens are particularly important because they were collected in the "Eje Neovolcánico," a physiographic region different from the "Sierra Madre del Sur," where the Guerrero collections came from. 


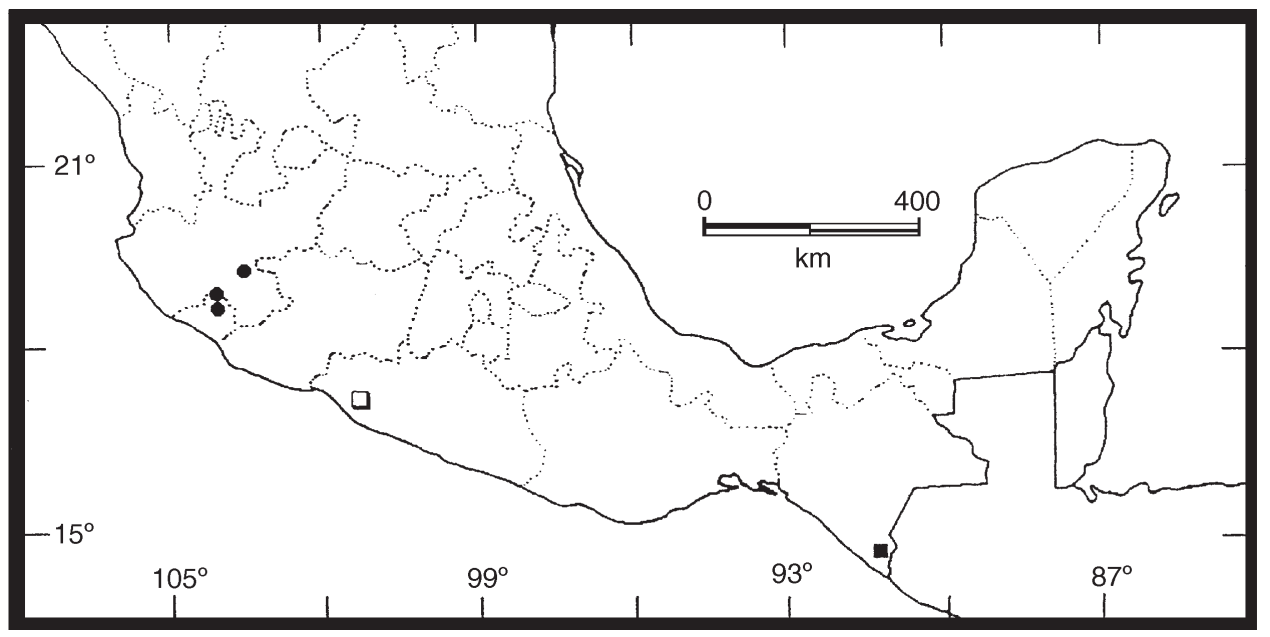

Fig. 2. Known collection sites of Cobaea lutea in Mexico. Chiapas (Sierra Madre de Chiapas); $\square$ Guerrero (Sierra Madre del Sur); Colima and Jalisco (Eje Neovolcánico).

We believe it is possible for $C$. lutea to occur farther north on the Pacific coast since other species of Cobaea have been found as far north as Nuevo León on the Atlantic slope (Hinton \& Hinton, 1995). More fieldwork is necessary to increase the presence of Cobaea specimens in herbaria.

Morphologically, the specimens collected at Las Moras in Jalisco (Lomelí No. 2928, 3446) and at Rancho El Jabalí in Colima (Sanders No. 11946) are unusual. The plants show densely long-villous pedicels, a condition previously unknown in C. lutea. Prather (1996) reported hairs longer than $4 \mathrm{~mm}$ on the pedicels of $C$. lutea. However, those hairs were never dense on the specimens examined. Whether the presence of densely long-villous pedicels is a result of phenotypic plasticity of the plants growing in drier environments (i.e., in tropical deciduous forest) or to other causes, is a subject for future study.

In support of the hypothesis proposed above to explain the presence of Cobaea lutea in tropical deciduous forest, we may say that this species appears to be sensitive to microclimate because at Las Moras, the majority of the population is restricted to the ravine. The few plants observed outside were precocious and started fruiting earlier. These plants also showed a reddish coloration and looked depauperate. Furthermore, Cobaea lutea is clearly an annual species. This habit allows it to bypass the severe shortage of water of the tropical lowlands during the dry season.

Cobaea might have originated in central Mexico (Grant, 1959) at a time when the climate in Mexico was cooler and wetter, as it was during much of the Cenozoic, when temperate forest elements migrated south into Mexico and covered extensive areas (Graham, 1973). Cobaea probably diversified in this wide-ranging temperate forest. 
When the climate in northern Latin America became warmer and drier in recent times, the populations of Cobaea receded together with the temperate forests to their present location, and are now present on the Pacific slope in western Mexico only as relicts in favored areas.

The presence of a few populations of Cobaea in tropical deciduous forest represents some of these relicts that have been able to survive in moist creeks despite the heat, the severe dry season of up to eight months, and the presence of other aggressive vines.

In this respect, we think that the annual, scandent habit, winged seeds and rapid vigorous growth have played a role in the competitive ability and ultimately the survivorship of Cobaea lutea in tropical habitats.

\section{ACKNOWLEDGMENTS}

We are thankful to René León-Maldonado for his valuable help in the course of this work. We would also like to thank Jorge Flores at Facultad de Ciencias Naturales y Agropecuarias, Universidad Autónoma de Guadalajara, for fieldwork support. We are indebted to herbarium curators who kindly provided information and access to their specimens and to two anonymous reviewers, whose valuable suggestions are here gratefully acknowledged.

\section{LITERATURE CITED}

Argüelles, E., R. Fernández \& S. Zamudio. 1991. Listado florístico preliminar del estado de Querétaro. Flora del Bajío y de Regiones Adyacentes II: 1-155. Instituto de Ecología, A.C. Pátzcuaro, Michoacán.

Barrios-Rodríguez, M. A. \& J. M. Medina-Cota. 1996. Estudio florístico de la Sierra de Pachuca, estado de Hidalgo. Instituto Politécnico Nacional. México, D.F. 140 pp.

Brako, L. \& J. L. Zarucchi. 1993. Catalogue of the flowering plants and Gymnosperms of Peru. Monogr. Syst. Bot. Missouri Bot. Gard. Vol. 45. St. Louis. 1286 pp.

Calderón de Rzedowski, G. 1985. Polemoniaceae. In: Rzedowski \& Rzedowski (eds.) Flora fanerogámica del Valle de México. Vol. II. Escuela Nacional de Ciencias Biológicas and Instituto de Ecología. México, D.F. pp. 257-262.

Day, A. G. \& R. Moran. 1986. Acanthogilia, a new genus of Polemoniaceae from Baja California, Mexico. Proc. California Acad. Sci. 44: 111-126.

Diego, N. \& L. Lozada. 1994. Estudios florísticos en Guerrero. No. 3. Laguna de Tres Palos. Facultad de Ciencias, Universidad Nacional Autónoma de México. México, D.F. 29 pp.

Fonseca, R. M. \& L. Lozada. 1993. Estudios florísticos en Guerrero. No. 1. Laguna de Coyuca. Facultad de Ciencias, Universidad Nacional Autónoma de México. México, D.F. 23 pp.

Gallardo, C. 1996. Estudios florísticos en Guerrero. No. 8. Parque ecológico "La Vainilla." Zihuatanejo, Guerrero. Facultad de Ciencias, Universidad Nacional Autónoma de México. México, D.F. 61 $\mathrm{pp}$.

Gibson, D. N. 1970. Polemoniaceae. In: Standley, P. C. \& L. O. Williams (eds.) Flora of Guatemala. Fieldiana, Bot. 24(9) parts I and II: 85-93.

Graham, A. 1973. History of the arborescent temperate element in the northern Latin American biota. In: Graham, A. (ed.). Vegetation and vegetational history of northern Latin America. Elsevier Scientific Publishing Company. Amsterdam. pp. 301-314. 
Grant, V. 1959. Natural history of the Phlox family: Systematic Botany. The Hague: Martinus Nijhoff. $280 \mathrm{pp}$.

Grant, V. 1998. Primary classification and phylogeny of the Polemoniaceae, with comments on molecular cladistics. Amer. J. Bot. 85: 741-752.

Gual, M. 1995. Estudios florísticos en Guerrero. No. 6. El Cañón del Zopilote. Área Venta Vieja. Facultad de Ciencias, Universidad Nacional Autónoma de México. México, D.F. 39 pp.

Guerrero-Nuño, J. J. \& G. A. López-Coronado. 1997. La vegetación y la flora de la Sierra de Quila, Jalisco, México. Universidad de Guadalajara. Guadalajara, Jalisco. 135 pp.

Hinton, J. \& G. S. Hinton 1995. Checklist of Hinton's collections of the flora of south central Nuevo León and adjacent Coahuila. Acta Bot. Mex. 30: 41-112.

Ippolito, A. \& A. V. Suárez. 1998. Flowering phenology and pollination of Cobaea aschersoniana (Polemoniaceae). Biotropica 30(1): 145-148.

Johnson, L. A., J. L. Schultz, D. E. Soltis, \& P. S. Soltis. 1996. Monophyly and generic relationships of Polemoniaceae based on matK sequences. Amer. J. Bot. 83: 1207-1224.

Labat, J. N. 1995. Végétation du nord-ouest du Michoacán, Mexique. Flora del Bajío y de Regiones Adyacentes VIII. Instituto de Ecología, A.C. Pátzcuaro, Michoacán. 401 pp.

Lott, E. J. 1985. Listados florísticos de México. III. La Estación de Biología Chamela, Jalisco. Herbario Nacional. Instituto de Biología, Universidad Nacional Autónoma de México. México, D.F. 30 pp.

Lozada, L. 1994. Estudios florísticos en Guerrero. No. 2. Laguna de Mitla. Facultad de Ciencias, Universidad Nacional Autónoma de México. México, D.F. 44 pp.

Peralta, S. 1995. Estudios florísticos en Guerrero. No. 5. Cañón del Zopilote (Área Papalotepec). Facultad de Ciencias, Universidad Nacional Autónoma de México. México, D.F. 37 pp.

Prather, L. A. 1996. Three new species of Cobaea (Polemoniaceae). Brittonia 48(1): 111-119.

Prather, L. A. 1999. Systematics of Cobaea (Polemoniaceae). Syst. Bot. Monogr. 57: 1-81.

Prather, L. A., C. J. Ferguson, \& R. K. Jansen. 2000. Polemoniaceae phylogeny and classification: Implications of sequence data from the chloroplast gene ndhF. Amer. J. Bot. 87: 1300-1308.

Rzedowski, J. \& R. McVaugh. 1966. La vegetación de Nueva Galicia. Contr. Univ. Mich. Herb. 9(1): 1-123.

Rzedowski, J. \& G. Calderón de Rzedowski. 1995. Familia Polemoniaceae. Flora del Bajío y de Regiones Adyacentes 33: 1-41.

Standley, P. C. 1914. A revision of the genus Cobaea. Contr. U.S. Natl. Herb. 17: 448-458.

Vargas, A. \& A. Pérez. 1996. Estudios florísticos en Guerrero. No. 7. Cerro Chiletépetl y alrededores (Cuenca del Balsas). Facultad de Ciencias, Universidad Nacional Autónoma de México. México, D.F. 49 pp.

Vázquez, J. A., R. Cuevas, T. S. Cochrane, H. H. Iltis, F. J. Santana \& L. Guzmán. 1995. Flora de Manantlán. Universidad de Guadalajara-Imecbio/University of Wisconsin-Madison. Sida, Botanical Miscellany 13: 312.

Verduzco, C. \& L. C. Rodríguez. 1995. Estudios florísticos en Guerrero. No. 4. El Rincón de la Vía. Facultad de Ciencias, Universidad Nacional Autónoma de México. México, D.F. 43 pp.

Weberbauer, A. 1945. El mundo vegetal de los Andes Peruanos. Ministerio de Agricultura, Perú. Lima. $776 \mathrm{pp}$. 